\title{
Guanine Ribonucleotide Depletion Inhibits T Cell Activation Mechanism of Action of the Immunosuppressive Drug Mizoribine
}

\author{
Laurence A. Turka, ${ }^{*}$ Jennifer Dayton, ${ }^{\star}$ Gary Sinclair, ${ }^{\star}$ Craig B. Thompson, ${ }^{\star \$ \|}$ and Beverly S. Mitchell** \\ Departments of Medicine, ${ }^{*}$ Pharmacology, ${ }^{\ddagger}$ and Microbiology/Immunology, ${ }^{\S}$ University of Michigan, \\ and the Howard Hughes Medical Institute," Ann Arbor, Michigan 48109
}

\begin{abstract}
The immunosuppressive drug, mizoribine, has been used to prevent rejection of organ allografts in humans and in animal models. Based on studies in cell lines, mizoribine has been postulated to be an inhibitor of inosine monophosphate (IMP) dehydrogenase (EC1.2.1.14), a pivotal enzyme in the formation of guanine ribonucleotides from IMP. To further characterize the mechanism of action of this drug, we studied the effect of mizoribine on human peripheral blood $T$ cells stimulated with alloantigen, anti-CD3 MAb, or pharmacologic mitogens. Mizoribine $(1-50 \mu \mathrm{g} / \mathrm{ml})$ was able to inhibit $T$ cell proliferation by 10 $100 \%$ in a dose-dependent fashion to all stimuli tested. Measurements of purine ribonucleotide pools by HPLC showed that mizoribine led to a decrease in intracellular GTP levels, and that repletion of GTP reversed its antiproliferative effects. We also examined sequential events occurring after $T$ cell stimulation. Early events in $\mathrm{T}$ cell activation, as assessed by steadystate mRNA levels of $c-m y c$, IL-2, $c-m y b$, histone, and cdc2 kinase, as well as surface IL-2 receptor expression, were unaffected. However, cell cycle analysis revealed decreased numbers of cells in S, G2, and M phases, and showed that the G1/S block was reversed with GTP repletion. These data indicate that mizoribine has an effect on $T$ cell proliferation by a mechanism distinct from that of cyclosporine or corticosteroids, and therefore may be useful in combination immunosuppressive regimens. (J. Clin. Invest. 1991. 87:940-948.) Key words: purine ribonucleotides $\bullet$ IMP dehydrogenase $\bullet$ transplantation $\bullet T$ cell activation $\cdot$ cell cycle
\end{abstract}

\section{Introduction}

The immunosuppressive drug, mizoribine (4-carbamoyl-1- $\beta$ D-ribofuranosylimidazolium-5-olate, also known as bredinin), has been shown to be an effective agent in organ transplantation. In animal models, mizoribine has shown a strong synergistic effect when used in combination with cyclosporine to prolong the survival of canine renal allografts (1-5), and rat cardiac and partial lung allografts (6). Mizoribine has also been used successfully as a primary immunosuppressive agent in human renal transplantation, with results comparable or supe-

Address correspondence and reprint requests to Dr. Laurence A. Turka, University of Michigan Medical Center, MSRB-II Room 1560. 1150 West Medical Center Drive, Ann Arbor, MI 48109-0676.

Received for publication 17 April 1990 and in revised form 10 September 1990.

J. Clin. Invest.

(C) The American Society for Clinical Investigation, Inc.

$0021-9738 / 91 / 03 / 0940 / 09 \$ 2.00$

Volume 87, March 1991, 940-948 rior to that of azathioprine, but without demonstrable myelosuppression or hepatotoxicity $(4,7-12)$.

Mizoribine is an imidazole nucleoside (Fig. 1), which was first isolated in 1974 from the soil fungus Eupenicillum brefeldianum (13). Mizoribine is metabolized to its monophosphate form by adenosine kinase (14), and has been postulated to inhibit inosine monophosphate (IMP) $^{1}$ dehydrogenase (EC1.2.1.14), an enzyme required for the synthesis of guanine nucleotides from IMP. Initial studies demonstrated that mizoribine inhibited the growth of murine lymphoma cells by interfering with guanine nucleotide metabolism (15). Subsequently, Ichikawa et al. found that mizoribine suppressed the proliferation of peripheral blood lymphocytes to lectins and alloantigens (16), but specific data on its metabolic effects were not provided.

The potential importance of guanine nucleotides in $\mathrm{T}$ cell function is suggested by a number of findings. Signal transduction through the $T$ cell receptor for antigen (TCR) is believed to be mediated by $\mathrm{G}$ protein coupling of the receptor to phospholipase $C(17)$. In addition, there is recent evidence implicating the $P 21^{\text {ras }}$ GTPase in T cell activation (18). Guanine nucleotides have also been suggested as second messengers in the alternate pathway of $\mathrm{T}$ cell activation mediated by the CD28 surface molecule, since CD28 stimulation raises intracellular cyclic guanosine monophosphate levels (19). Finally, deficiency of the enzyme purine nucleoside phosphorylase is associated with perturbed levels of guanine ribonucleotides and severely deficient $T$ cell immunity (20). These observations suggest that the ability of mizoribine to block $\mathrm{T}$ cell proliferation might be due to its interference with physiologic guanine nucleotide metabolism, thereby blocking $\mathrm{T}$ cell proliferation at the level of signal transduction or at some more distal point in the activation pathway.

To further examine the effects of mizoribine on $\mathrm{T}$ cell proliferation, we used purified $T$ lymphocytes, free of contamination by $B$ cells and macrophages. These accessory cell-depleted $T$ lymphocytes do not respond to soluble antigen or lectins, but can be stimulated with monoclonal antibodies directed against either the TCR, or the CD3 complex of proteins, which is intimately associated with the TCR in the cell membrane (21). TCR/CD3 signaling activates protein kinase $\mathrm{C}$ and induces a rise in intracellular calcium, effects that can be mimicked with the combination of phorbol ester and a calcium ionophore (e.g., ionomycin) (21). The experiments described here have used both sets of stimuli in order to determine whether mizoribine interfered with cell surface signaling events or acted at a more distal point in the activation pathway.

Our studies were undertaken to ask whether mizoribine

1. Abbreviations used in this paper: IL-2R, IL-2 receptor; IMP, inosine monophosphate. 

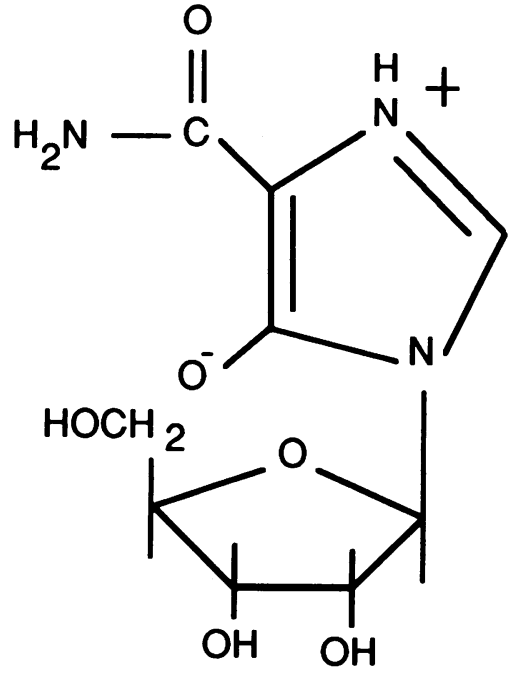

Figure 1. Chemical

structure of the nucleoside antibiotic mizoribine (4carbamoyl-1- $\beta$-Dribofuranosylimidazolium5-olate).

specifically perturbed guanine ribonucleotide pools, and if so, to determine at what point guanine ribonucleotide depletion had its effect on stimulated $T$ cells. Using highly purified $T$ cells, we have found that the inhibition of $T$ cell proliferation by mizoribine is associated with a decrease in intracellular GTP and is reversible with GTP repletion. Despite this proliferative inhibition, mizoribine did not block early events in T cell activation such as IL-2 or IL-2R expression, although the entry of cells into $\mathrm{S}$ phase was severely impaired. Taken together, our data suggest that mizoribine blocks $T$ cell proliferation via a guanine ribonucleotide-dependent mechanism that prevents cells from exiting $\mathrm{G} 1$ and entering $S$ phase.

\section{Methods}

Monoclonal antibodies (MAbs). The mouse anti-human MAbs 9.3 (anti-CD28), G19-4 (anti-CD3), 9.6 (anti-CD2), G17-2 (anti-CD4), and G10.1 (anti-CD8) were produced as previously described (22-25). FITC- and phycoerythrin-conjugated nonspecific isotype-matched control antibodies, and FITC-conjugated IL-2R (anti-CD25) were purchased from Coulter Immunology, Inc., (Hialeah, FL). FITC-labeled WT-31 (anti-T cell receptor $\beta$ chain) was purchased from Becton Dickinson \& Co. (Mountain View, CA), and FITC-labeled goat anti-mouse IgG2a and IgG1 were purchased from FisherBiotech (Orangeburg, NY).

Reagents. Mizoribine (mol wt 259) was a generous gift of Dr. N. Kamatani (Tokyo Women's Medical College, Tokyo, Japan). Cyclosporine was kindly provided by Carl $\mathrm{H}$. June (Naval Medical Research Institute, Bethesda, MD). Ionomycin was obtained from CalbiochemBehring Corp. (San Diego, CA). Phorbol myristate acetate (PMA) was purchased from Sigma Chemical Co. (St. Louis, MO), and reconstituted as a $1 \mathrm{mg} / \mathrm{ml}$ solution in dimethylsulfoxide. Fresh working dilutions of PMA (at $5 \mu \mathrm{g} / \mathrm{ml}$ in PBS) were prepared as needed for each experiment. Guanosine and 8-aminoguanosine were also obtained from Sigma Chemical Co.

Isolation of peripheral blood lymphocytes. All blood donors were healthy volunteers who gave informed consent to venipuncture. Peripheral blood mononuclear cells were isolated from venous blood by density gradient centrifugation using Ficoll-Hypaque. When specified, purified $\mathrm{T}$ cells were obtained using a protocol previously described (26). Briefly, T cells were negatively selected for by incubating the unseparated mononuclear cells with saturating amounts of MAbs directed at CD11, CD20, CD16, CD14, and HLA-DR followed by separation using goat anti-mouse immunoglobulin-coated magnetic beads (Advanced Magnetics Institute, Cambridge, MA). Cell purity was moni- tored by staining the negatively selected cells with FITC-conjugated MAbs directed at CD2, and was always $>98 \%$ positive as compared with staining with a nonspecific control MAb.

Cell culture. Cells were cultured in complete medium consisting of RPMI-1640, $10^{5} \mathrm{U} /$ liter penicillin, $100 \mu \mathrm{g} /$ liter streptomycin, $5 \mathrm{mM}$ Hepes, $2 \mathrm{mM}$ L-glutamine, and $10 \%$ fetal calf serum. All products were purchased from Gibco Laboratories (Grand Island, NY). Cells were cultured at a density of $1 \times 10^{6} / \mathrm{ml}$. When used, anti-CD3 antibody was immobilized on plastic culture dishes using a $1 \mu \mathrm{g} / \mathrm{ml}$ solution (27). The concentration of 9.3 MAb used in cell cultures was always $1 \mu \mathrm{g} / \mathrm{ml}$. PMA was used at a final concentration of $3 \mathrm{ng} / \mathrm{ml}$, ionomycin at 125 $\mathrm{ng} / \mathrm{ml}$, guanosine at $50 \mu \mathrm{M}$, and 8-aminoguanosine at $100 \mu \mathrm{M}$. To stimulate cells in mixed lymphocyte reactions (MLRs), cells were cultured with an equal number of irradiated $\left(3,000 \mathrm{R},{ }^{137} \mathrm{Cs}\right.$ source $)$ allogeneic peripheral blood mononuclear cells. When used, mizoribine was added simultaneously with the stimulating agents.

Proliferative assays. Cells were cultured in complete medium in 96-well round-bottomed microtiter plates at $5 \times 10^{4}$ cells/well in a total volume of $0.2 \mathrm{ml}$. Proliferation, measured as DNA synthesis, was determined by adding $1 \mu \mathrm{Ci}$ of $\left[{ }^{3} \mathrm{H}\right]$ thymidine (ICN Pharmaceuticals, Inc., Irvine, CA) to each well for the last $6 \mathrm{~h}$ of culture, after which plates were harvested with a PHD 200 Cell Harvesting System (Cambridge Technology, Inc., Cambridge, MA). MLRs were harvested after $6 \mathrm{~d}$, and all other cultures were harvested after $72 \mathrm{~h}$, except as noted. All assays were performed in quadruplicate.

Analysis of cell surface phenotype. $1 \times 10^{6}$ cells were washed twice, mixed with a saturating amount of the appropriate FITC- or PE-conjugated antibody, and suspended in $100 \mu \mathrm{l}$ of a solution of $50 \%$ fetal calf serum and $50 \%$ PBS containing $0.1 \%$ sodium azide. Cells were incubated for $45 \mathrm{~min}$ at $4^{\circ} \mathrm{C}$, washed twice with cold PBS, and resuspended in $0.5 \mathrm{ml}$ PBS with $1 \%$ formaldehyde for flow cytometric analysis. When unlabeled MAbs were used, cells were first incubated as indicated above with the unlabled antibody, washed twice, and stained in a similar fashion with FITC-conjugated goat anti-mouse Ab before fixation in $1 \%$ formaldehyde.

Single- and dual-color fluorescent analyses were performed on a FACScan $^{\circledR}$ (Becton Dickinson, Mountain View, CA). Positive cells were defined as those with fluorescent intensity beyond a threshold defined by the negative control (cells stained with isotype-matched nonspecific mouse immunoglobulin). Dead cells were excluded from analysis using forward and right-angle light-scatter gating. Electronic subtraction was used to correct for spectral emission overlap from the green into the red channel. Cell staining was measured in arbitrary units as the log of fluorescent intensity, and in all cases is displayed on a four decade scale.

Analysis of DNA content. $1 \times 10^{6}$ cells were washed twice with HBSS and resuspended at $1-2 \times 10^{6}$ cells $/ \mathrm{ml} .2 .5$ vol of ice-cold $70 \%$ ethanol were added over 1-1.5 min while vortexing. The fixed cells were washed twice with HBSS, resuspended in a solution of $18 \mu \mathrm{g} / \mathrm{ml}$ propidium iodide and $40 \mu \mathrm{g} / \mathrm{ml} \mathrm{RNAse}$, and incubated for $16 \mathrm{~h}$. Analysis of DNA content was performed on an Epics $C$ cell sorter (Coulter Electronics, Inc.) within $24 \mathrm{~h}$ of propidium iodide staining. Analysis of cell cycle was done using the Paral software program. Results are expressed as fluorescent intensity on a linear scale using arbitrary units.

Northern blot analysis. Cells were harvested from cultures by resuspension and centrifugation, and total cellular RNA was extracted with guanidinium isothiocyanate (28). The samples were equalized for ribosomal RNA, and the equalization was confirmed by ethidium bromide staining of equal amounts of the RNA samples on a nondenaturing $1 \%$ agarose gel as previously described (29). These equalized RNA samples $(5-10 \mu \mathrm{g})$ were separated on $1 \%$ agarose-formaldehyde gels and transferred to nitrocellulose. Membranes were baked under a vacuum for 2 $h$ and then prehybridized (30). The DNA probes used were labeled by nick translation and hybridized to the membranes as previously described (30), after which the membranes were exposed to x-ray film at $-70^{\circ} \mathrm{C}$.

DNA probes. The probes used in these experiments were gene-specific inserts isolated from low melting point agarose gels after digestion 
of the plasmid in which they were propagated with the appropriate restriction endonucleases. The probes used include HLA-B7 (1.4 kb [31]), human $c-m y c$ (2.5 kb [32]), IL-2 (1.0 kb [33]), histone (1.4 kb [34]), $c-m y b$ (3.4 kb, gift of Michael Clarke, University of Michigan), human cdc2 kinase (35) (1.1 kb; gift of Jeffry Corden, Johns Hopkins School of Medicine, Baltimore, MD).

Measurement of ATP and GTP. Nucleotide pools were quantified using HPLC on a Partisil-10 SAX anion exchange column (Whatman, Clifton, NJ). 5-10 $\times 10^{6}$ cells were harvested and counted at the indicated time points, and washed twice. Cell viability, assessed by trypan blue exclusion, always exceeded $95 \%$. The cells were then resuspended in $150 \mu \mathrm{l}$ PBS and extracted with $170 \mu$ lof ice-cold $1 \mathrm{~N}$ perchloric acid. After $5 \mathrm{~min}$ at $4^{\circ} \mathrm{C}$, the extract was neutralized with $1 \mathrm{~N} \mathrm{KOH}$. The volume of sample analyzed was adjusted for cell count, and 50-100 $\mu \mathrm{l}$ of the supernatant was injected for each analysis. Ribonucleoside triphosphates were separated using a linear gradient from $80 \%$ buffer $\mathrm{A}$ $\left(0.002 \mathrm{M} \mathrm{NH}_{4} \mathrm{H}_{2} \mathrm{PO}_{4}, \mathrm{pH} 2.8\right)$ to $90 \%$ buffer $\mathrm{B}\left(0.75 \mathrm{M} \mathrm{NH}_{4} \mathrm{H}_{2} \mathrm{PO}_{4}, \mathrm{pH}\right.$ 3.9 ) over $30 \mathrm{~min}$ at a flow rate of $2 \mathrm{ml} / \mathrm{min}$. The individual nucleotide concentrations were calculated by comparing areas of peaks absorbing at $254 \mathrm{~nm}$ to the areas generated by $\mathrm{nmol}$ amounts of pure standards using a 3390A Hewlett Packard integrator.

\section{Results}

Mizoribine blocks mitogen and alloantigen-induced $T$ cell activation. Since mizoribine has been found to be effective in preventing organ allograft rejection, we first examined the effects of the drug on $T$ cell proliferation induced by a variety of mitogenic stimuli. T cells were purified as described (except for MLRs where unseparated mononuclear cells were used) and cultured with increasing concentrations of mizoribine. Table I displays a representative experiment (one of four independent experiments) showing that mizoribine blocked $T$ cell proliferation induced by anti-CD3 MAbs, alloantigen, and PMA plus either ionomycin, anti-CD28 MAbs, or both. This effect was dose dependent, and the concentration at which $50 \%$ inhibition was seen $\left(\mathrm{IC}_{50}\right)$ varied from $<1 \mu \mathrm{g} / \mathrm{ml}$ for CD3 stimulation, to $\sim 5 \mu \mathrm{g} / \mathrm{ml}$ for PMA-induced stimulation. A concentration of $50 \mu \mathrm{g} / \mathrm{ml}$ of mizoribine suppressed proliferation to the level of medium control for every stimulus tested. Similar results were obtained when cultures were harvested at a variety of time points before and beyond the usual culture period, demonstrating that these effects of mizoribine were not a time-dependent phenomenon (data not shown).
Mizoribine and cyclosporine additively block $T$ cell proliferation. The fact that mizoribine inhibited $\mathrm{T}$ cell proliferation induced by phorbol ester plus anti-CD28 MAb (Table I), a mitogenic combination we have previously shown to be resistant to cyclosporine immunosuppression (36), suggested that the two drugs act via distinct mechanisms and might have an additive effect in vitro. To examine this possibility, purified $\mathrm{T}$ cells were stimulated with immobilized anti-CD3 MAbs in the presence of varying concentrations of mizoribine and cyclosporine. Fig. 2 shows that mizoribine and cyclosporine acted additively to inhibit proliferation induced via TCR/CD3 stimuli. For example, the combination of $5 \mu \mathrm{g} / \mathrm{ml}$ of mizoribine and $10 \mathrm{ng} / \mathrm{ml}$ of cyclosporine block proliferation to approximately the same level as is seen with $100 \mathrm{ng} / \mathrm{ml}$ of cyclosporine alone. These in vitro findings are consistent with the observation that mizoribine and cyclosporine act cooperatively to prolong allograft survival in animal models $(1,2,4)$.

Alterations in GTP levels with mizoribine. Mizoribine has been reported to be an inhibitor of IMP dehydrogenase, an enzyme which catalyzes the first step in the conversion of IMP to guanosine monophosphate. Therefore, we next studied the effect of mizoribine on purine ribonucleotide levels in activated T cells. Purified T cells were stimulated with the combination of PMA, ionomycin, and anti-CD28 MAb. These agents were chosen since all three appear to play distinct and independent roles in $T$ cell activation, and their combination has been previously shown to lead to maximal $\mathrm{T}$ cell proliferation and lymphokine production (37). The cells were harvested $72 \mathrm{~h}$ after stimulation for analysis of purine ribonucleotide pools by HPLC (see Methods) and for measurement of DNA synthesis (Fig. 3). Mizoribine caused a dose-related depletion of GTP in activated T cells $(A)$, which closely paralleled its effect on proliferation $(C)$. A small diminution of ATP levels $(B)$, which did not appear to correlate with proliferative inhibition, was observed. Further evidence against a role for adenine nucleotide depletion by mizoribine was the inability of adenine supplementation of the media to reverse the proliferative inhibition of the drug (data not shown).

In order to examine the effect of lymphocyte activation on GTP levels and the time course of GTP depletion induced by mizoribine, GTP levels were serially measured in cells cultured in the presence and absence of $10 \mu \mathrm{g} / \mathrm{ml}$ of mizoribine (Fig. 4).

Table I. Mizoribine Blocks Mitogen or Alloantigen-dependent T cell Proliferation

\begin{tabular}{|c|c|c|c|c|c|}
\hline Miz & CD3 & PMA + Iono & PMA + CD28 & PMA + Iono + CD28 & MLR \\
\hline$(\mu g / m l)$ & $c p m^{*}$ & $c p m^{*}$ & $c p m^{*}$ & $c p m^{*}$ & $c p m^{*}$ \\
\hline 0 & $167,630 \pm 14,566$ & $43,716 \pm 6,466$ & $26,933 \pm 3,625$ & $35,154 \pm 8,246$ & $56,497 \pm 4,925$ \\
\hline 1 & $32,390 \pm 2,983$ & $32,249 \pm 1,930$ & $21,018 \pm 1,400$ & $24,574 \pm 5,541$ & $33,457 \pm 6,007$ \\
\hline 2 & ND & $25,758 \pm 2,888$ & $24,798 \pm 2,699$ & $21,936 \pm 1,923$ & ND \\
\hline 5 & $19,192 \pm 612$ & $14,918 \pm 1,096$ & $19,377 \pm 651$ & $15,258 \pm 1,522$ & $9,296 \pm 1,127$ \\
\hline 10 & $7,734 \pm 656$ & $7,854 \pm 333$ & $9,309 \pm 686$ & $8,470 \pm 532$ & $2,980 \pm 199$ \\
\hline 50 & $611 \pm 73$ & $866 \pm 125$ & $1,293 \pm 32$ & $1,115 \pm 113$ & $424 \pm 69$ \\
\hline
\end{tabular}

* Cells were cultured for $72 \mathrm{~h}$ in 96-well microliter plates except for MLRs which were cultured for $6 \mathrm{~d}$. The anti-CD3 mAb G19-4 was immobilized on the tissue culture plate using a $1 \mu \mathrm{g} / \mathrm{ml}$ solution. PMA was used at $3 \mathrm{ng} / \mathrm{ml}$, ionomycin (Iono) at $125 \mathrm{ng} / \mathrm{ml}$, and the anti-CD28 mAb 9.3 at $1 \mu \mathrm{g} / \mathrm{ml}$. For MLRs equal numbers of responder and irradiated stimulating cells were used. All cultures were pulsed with $1 \mu \mathrm{Ci}$ of tritiated thymidine $6 \mathrm{~h}$ before harvesting. Unstimulated cells incorporated $778 \pm 237 \mathrm{cpm}$ of thymidine at $72 \mathrm{~h}$ (culture duration for mitogenic stimuli) and $10,423 \pm 2155 \mathrm{cpm}$ at $6 \mathrm{~d}$ (culture period for MLRs). Values are mean \pm SD. 


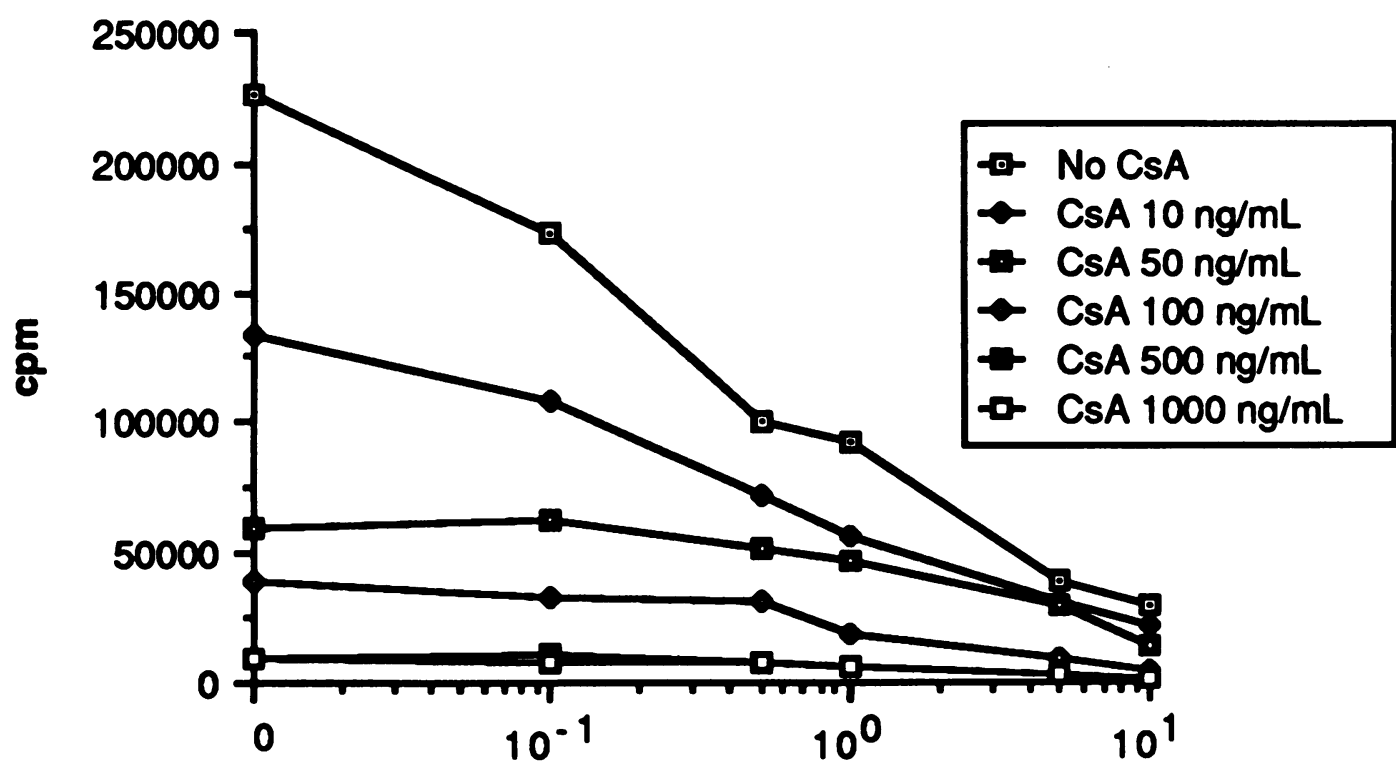

Figure 2. Additive effects of mizoribine and cyclosporine. Purified T cells were stimulated to proliferate with immobilized anti-CD3 MAb with varying concentrations of mizoribine and cyclosporine. Cells were plated in 96-well round bottom plates and cultured for $72 \mathrm{~h}$. Proliferation, measured as DNA synthesis and indicated as counts per minute, was determined by adding $1 \mu \mathrm{Ci}$ of $\left[{ }^{3} \mathrm{H}\right]-$ thymidine to each well for the last $18 \mathrm{~h}$ of culture, after which plates were Log Mizoribine Concentration ( $\mu \mathrm{g} / \mathrm{ml})$

Lymphocyte activation induced a fivefold increase in GTP levels at $72 \mathrm{~h}$. Upon cell stimulation, mizoribine slowed the initial accumulation of GTP and reduced subsequent levels by 35$55 \%$, although GTP content eventually exceeded unstimulated values. Intracellular GTP levels at $72 \mathrm{~h}$ were equivalent in cells that had been exposed to mizoribine for $7 \mathrm{~h}, 24 \mathrm{~h}$, or the entire culture period. Thus, mizoribine caused the same degree of GTP depletion whether it was added at culture initiation or at a later time point.

To determine if repletion of intracellular GTP could reverse the inhibitory effects of mizoribine, parallel cultures (stimulated with PMA, ionomycin, and anti-CD28 MAb) were
A. GTP Levels

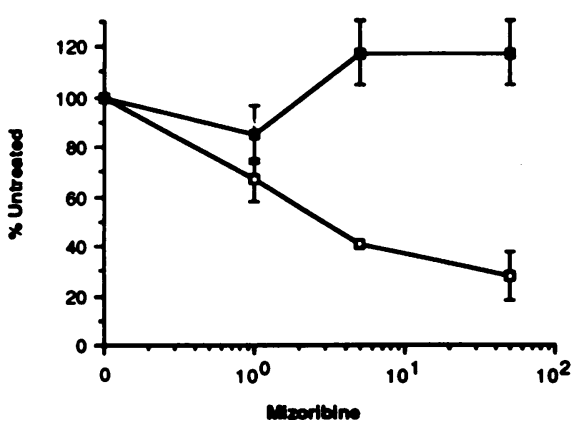

C. Prollferation - PMA + lono + anth-CD28

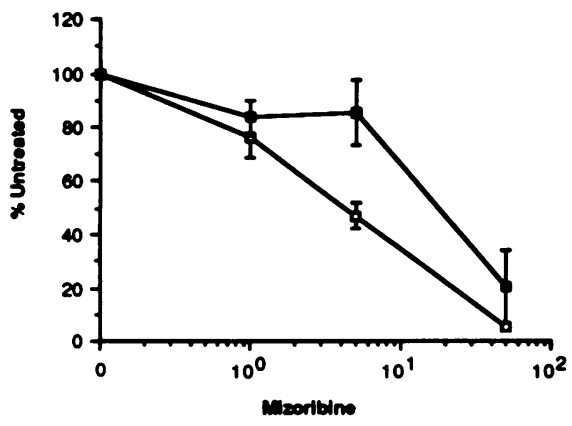

B.

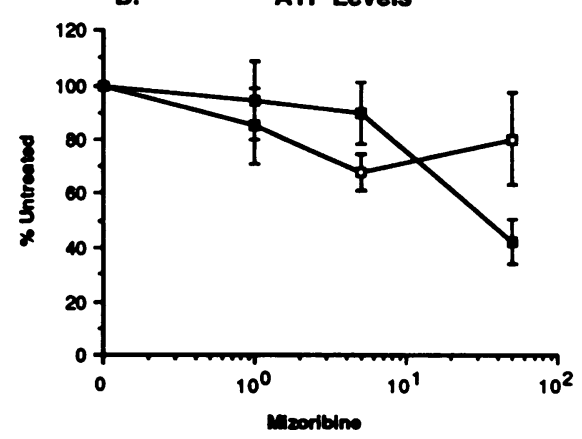

D. Prollferation - antt-CD3

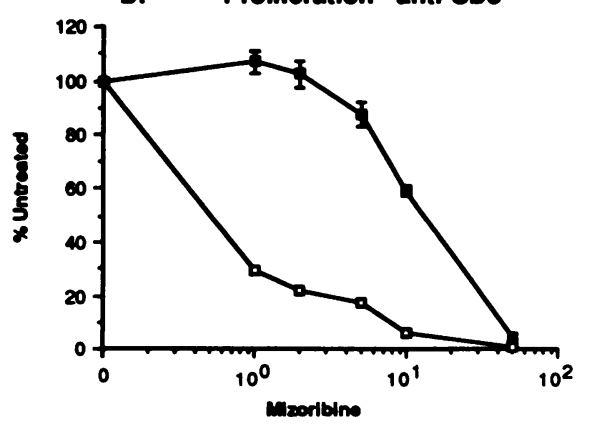

Figure 3. Alterations in GTP levels with mizoribine and effects of GTP repletion. Purified $T$ cells were stimulated with a combination of PMA, plus ionomycin, plus anti-CD28 MAb $(A$, $B$, and $C$ ), or with antiCD3 MAb (D). Control (一 -); GTP repletion (一- -). Cultures were performed with varying concentrations of mizoribine, and in paired cultures guanosine plus 8-aminoguanosine were used to replete intracellular GTP. The cells were harvested after $72 \mathrm{~h}$, at which point the perchloric acid extracts were analyzed for GTP and ATP content by HPLC, and proliferation was determined by $\left[{ }^{3} \mathrm{H}\right]-$ thymidine incorporation. All values are expressed as a percentage of the

results in untreated cultures (those not containing mizoribine) and are the mean $\pm \mathrm{SE}$ of three independent experiments (except $D$, which shows the mean $\pm \mathrm{SE}$ of replicates from a single experiment). Untreated baseline values are as follows: $(A)(G T P)$, control $-0.483 \mathrm{nmol} / 10^{6}$ cells, GTP repleted $-1.59 \mathrm{nmol} / 10^{6}$ cells; $(B)(A T P)$, control $-1.32 \mathrm{nmol} / 10^{6}$ cells, GTP repleted $-0.71 \mathrm{nmol} / 10^{6}$ cells; $(C)$ (proliferation), control $12,079 \mathrm{cpm}$, GTP repleted $-22,887 \mathrm{cpm} ;(D)$ (proliferation), control $-149,856 \mathrm{cpm}$, GTP repleted $-229,990 \mathrm{cpm}$. 


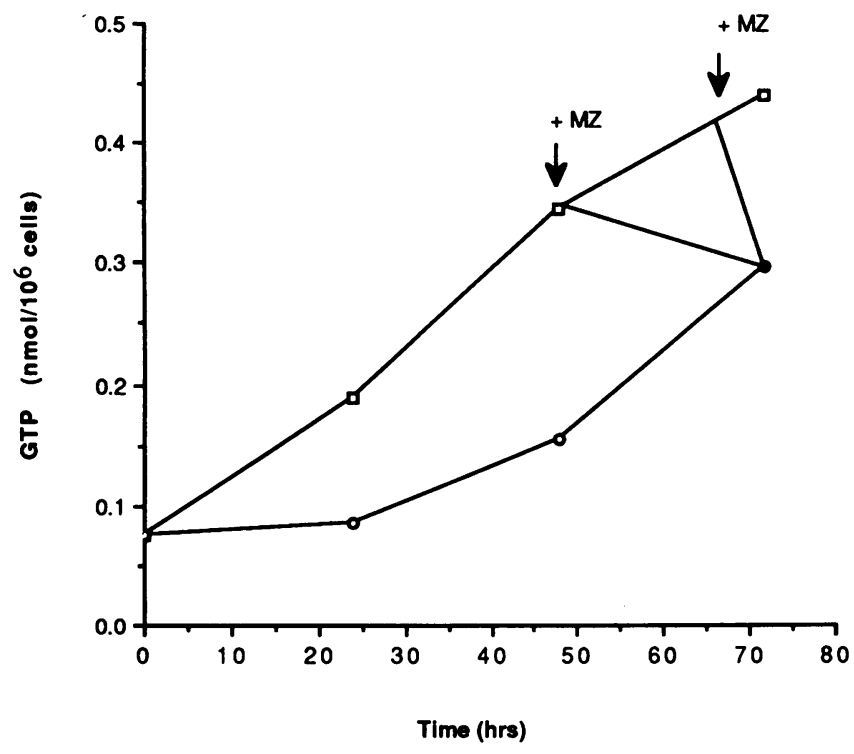

Figure 4. Time course of alterations in GTP levels. Purified T cells were stimulated with PMA and ionomycin. Cells were cultured in the absence (squares) or presence (circles) of $10 \mu \mathrm{g} / \mathrm{ml}$ of mizoribine, which was added either at culture initiation, or 7 or $24 \mathrm{~h}$ before harvesting (time of addition indicated by arrows). Samples were harvested at 24,48 , and $72 \mathrm{~h}$, extracted with perchloric acid, and analyzed for GTP content by HPLC.

plated containing $50 \mu \mathrm{M}$ guanosine plus $100 \mu \mathrm{M}$ 8-aminoguanosine. We have previously shown that in cultured $\mathrm{T}$ and $\mathrm{B}$ lymphoblasts the combination of guanosine and 8-aminoguanosine at these concentrations results in a sustained rise in intracellular concentrations of GTP, whereas guanosine alone results in more transient increases (38). This effect is mediated by the slow conversion of guanosine to guanine in the presence of 8-aminoguanosine, a weak competitive inhibitor of the degradatory enzyme purine nucleoside phosphorylase (39). 8Aminoguanosine alone had no effect on the mizoribine-induced inhibition of $\mathrm{T}$ cell proliferation (data not shown). However, the combination of guanosine and 8-aminoguanosine augmented proliferation in the absence of mizoribine, and completely reversed the anti-proliferative effects of mizoribine at concentrations up to $5 \mu \mathrm{g} / \mathrm{ml}$ (Fig. 3, $C$ and $D$ ). This combination similarly reversed the inhibitory effects of mizoribine when $\mathrm{T}$ cells were stimulated to proliferate with anti-CD3 MAb (Fig. 3 D). Measurement of ATP and GTP pools by HPLC confirmed that intracellular GTP levels had been restored to control values in cultures containing guanosine and 8-aminoguanosine (Fig. 3, $A$ and $B$ ). It is notable that at the highest doses of mizoribine used, $50 \mu \mathrm{g} / \mathrm{ml}$, the addition of guanosine and 8-aminoguanosine did not restore proliferation, despite the fact that GTP levels were unchanged. This was not due to a direct toxic effect of the drug, since cell viability as assessed by trypan blue exclusion was not altered by this dose of mizoribine. Rather, it suggests that mizoribine may have additional mechanisms of action which are physiologically important only at high concentrations of the drug.

Mizoribine does not interfere with early events in $T$ cell activation. The traditional assay of proliferation by DNA synthesis measures an event that occurs during $S$ phase of the cell cycle. Having found that mizoribine blocked DNA synthesis, we now sought to determine whether events occurring earlier in the cell cycle (i.e., in G1) were similarly inhibited. Thus purified T cells were stimulated with PMA plus ionomycin plus anti-CD28 MAb in the absence or presence of $10 \mu \mathrm{g} / \mathrm{ml}$ of mizoribine, and the cells were harvested at 6 and $24 \mathrm{~h}$. Total cellular RNA was extracted and analyzed by Northern blotting (Fig. 5). A concentration of $10 \mu \mathrm{g} / \mathrm{ml}$ of mizoribine was used since this exceeded the $\mathrm{IC}_{50}$ of the drug for this particular mitogenic stimulus. In the experiment shown, proliferation (measured on day 3$)$ was inhibited by $71 \%(14,869 \pm 1589$ vs. 4272 \pm 512 ). As shown in Fig. 5 mizoribine did not block the expression of the nuclear protooncogene, $c-m y c$, a gene expressed very early after $T$ cell activation, independent of new protein synthesis $(40)$. To determine whether mizoribine blocked entry of the cells into the G1 phase of the cell cycle we also analyzed steady-state mRNA levels for cdc2 kinase, a gene expressed at the $\mathrm{R}$ (restriction) point in $\mathrm{G} 1$, after which the cell becomes committed to mitosis and is unable to return to G0 (41). As was the case for $c-m y c$, cdc2 kinase levels were not significantly altered in mizoribine-treated cultures (Fig. 6). Mizoribine also did not affect the expression of either histone or $c-m y b$, both of which are expressed late in G1 (data not shown) (41).

$I L-2$ and $I L-2 R$ expression is unimpaired by mizoribine. Since mizoribine did not appear to interfere with the general process of $\mathrm{T}$ cell activation, we next asked whether mizoribine interfered with the specific induction of the $T$ cell growth factor IL-2 or its receptor (IL-2R). To test for IL-2 expression Northern blots prepared as above were hybridized with an IL-2-specific cDNA probe (Fig. 5). Similar to what we observed with

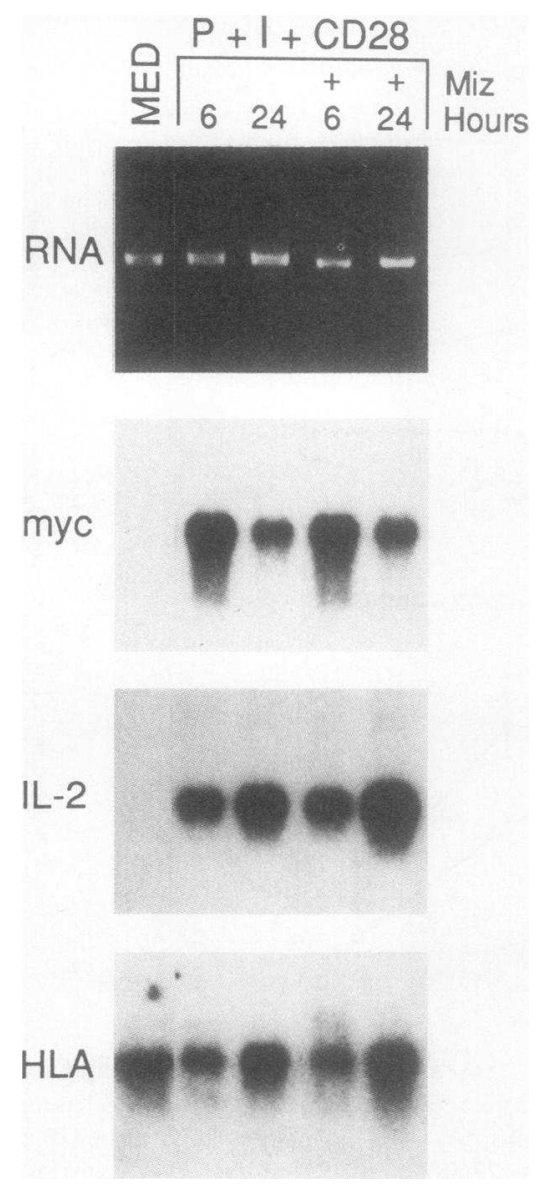

Figure 5. Mizoribine does not block expression of genes associated with $\mathrm{T}$ cell activation. Purified T cells were cultured with medium alone (MED) or with a combination of PMA $(P ; 3 \mathrm{ng} / \mathrm{ml})$ plus ionomycin $(I ; 125$ $\mu \mathrm{g} / \mathrm{ml}$ ) plus anti-CD28 $\operatorname{MAb}(1 \mu \mathrm{g} / \mathrm{ml})$ in the absence or presence of mizoribine (Miz; $10 \mu \mathrm{g}$ / $\mathrm{ml}$ ) and harvested at the indicated time points. RNA was isolated and equalized on $1 \%$ agarose gels (top). Northern blots were prepared and the filters were hybridized sequentially with cDNA probes for $c$-myc, IL-2, and HLA. 


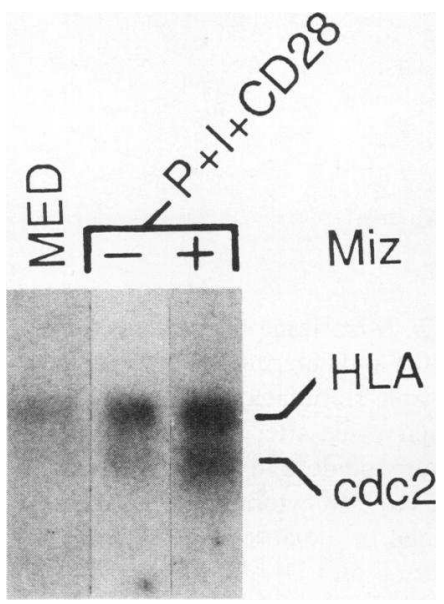

Figure 6. Mizoribine does not block the expression the cdc2 kinase gene. Purified $T$ cells were cultured with medium alone $(M E D)$ or with a combination of PMA $(P ; 3 \mathrm{ng} / \mathrm{ml})$ plus ionomycin $(I ; 125 \mu \mathrm{g} / \mathrm{ml})$ plus antiCD28 MAb $(1 \mu \mathrm{g} / \mathrm{ml})$ in the absence or presence of mizoribine (Miz; $10 \mu \mathrm{g} / \mathrm{ml}$ ) and harvested at $24 \mathrm{~h}$. RNA was isolated and equalized on $1 \%$ agarose gels. Northern blots were prepared and hybridized with a cDNA probe for cdc2 kinase. The lower band in each lane is

the cdc2 kinase transcript, and the upper band is the HLA transcript. The cdc 2 kinase:HLA ratio determined by scanning densitometry was $\mathbf{0 . 4 8}$ for cell stimulated in the absence of mizoribine (middle lane) and 0.64 for cells stimulated in the presence of mizoribine (right lane).

$c-m y c$ and cdc2 kinase mRNA levels, mizoribine did not block the expression of IL-2 mRNA. The small increase in IL-2 mRNA seen in the mizoribine-treated culture is accounted for by the slightly higher amount of HLA message found in that sample.

Flow cytometry was used to measure IL-2R induction, and as shown in Fig. 7 no significant effect on surface IL-2R expression was seen at concentrations of mizoribine up to $10 \mu \mathrm{g} / \mathrm{ml}$ in cells stimulated with PMA plus ionomycin plus anti-CD28 MAb. Mizoribine did not affect the forward or side light scatter profiles of cells harvested from these cultures, indicating again that $\mathrm{T}$ cells became activated with a concomitant increase in size and granularity. Similar results were obtained when $T$ cells were stimulated with anti-CD3 MAb (data not shown). In addition, mizoribine did not alter the percentage of lymphoblasts that stained positive for CD4, CD8, CD28, or the TCR $\beta$ chain (data not shown). At a concentration of $50 \mu \mathrm{g} / \mathrm{ml}$ of mizoribine, moderate decreases in both IL-2R expression and light scatter were seen. This observation, coupled with the inability of GTP repletion to reverse the proliferative inhibition of 50 $\mu \mathrm{g} / \mathrm{ml}$ of mizoribine (Fig. 3), further suggests there may be additional mechanisms of action of mizoribine at high concentrations.

Mizoribine blocks the movement of cells from $G 1$ to $S$ phase of the cell cycle. Since it was demonstrated that mizoribine did not block the initial steps of $T$ cell activation, we utilized cell cycle analysis to further characterize the point at which mizoribine inhibited $T$ cell proliferation. Cells were stimulated with anti-CD3 MAb, harvested after $48 \mathrm{~h}$, and stained with propidium iodide before flow cytometry. As seen in Fig. $8(A$ and $C)$, cultures containing mizoribine contained significantly decreased numbers of cells in S, G2, and $M$ phases of the cell cycle. Supporting the importance of this observation, GTP repletion using guanosine plus 8-aminoguanosine restored the normal progression to $S$ phase in mizoribine-treated cultures (Fig. 8, $B$ and $D$ ). Since mizoribine did not block the expression of the G1-associated genes, $c-m y c$ and IL-2, this result confirms that mizoribine blocks the movement of cells from G1 to $S$.

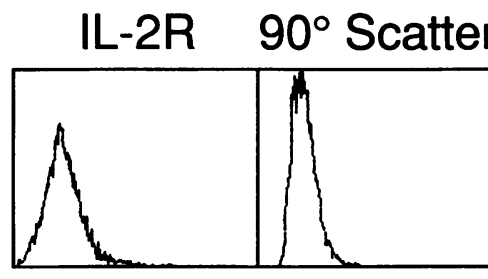

Unstimulated
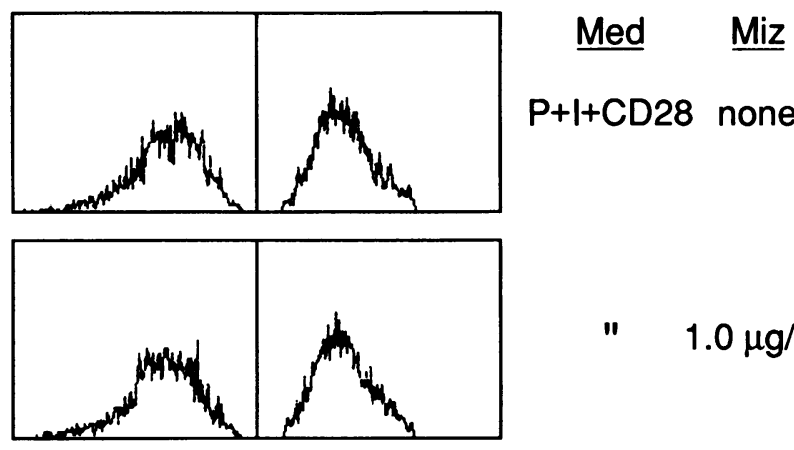

II

$1.0 \mu \mathrm{g} / \mathrm{ml}$

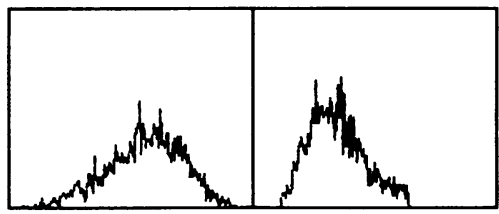

"

$10.0 \mu \mathrm{g} / \mathrm{ml}$

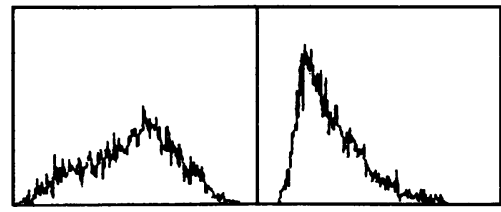

" $\quad 50.0 \mu \mathrm{g} / \mathrm{ml}$

Figure 7. Mizoribine does not affect the expression of IL-2 receptor on activated T cells. Purified T cells were stimulated in culture medium (Med) containing PMA plus ionomycin plus anti-CD28 MAb $(P+I+C D 28)$ in the absence or presence of varying concentrations of mizoribine (Miz), and harvested after $48 \mathrm{~h}$. Both stimulated and unstimulated cells were stained with FITC-conjugated anti-IL-2 receptor MAb, or FITC-conjugated nonspecific mouse Ig as a negative control (not shown). For clarity, each panel shows only anti-IL-2R staining, and fluorescent intensity is displayed on the $x$-axis in arbitrary units on a $4 \log$ scale. The $y$-axis indicates cell number. In each instance background staining with the nonspecific mouse Ig was similar to the pattern of IL-2R staining seen on the unstimulated cells (top). Unstained cells were also analyzed by flow cytometry to determine $90^{\circ}$ light scatter profiles, which is displayed in arbitrary units on a linear scale.

\section{Discussion}

Over the past $25 \mathrm{yr}$, a variety of immunosuppressive agents have become available for research and clinical use. Concurrently, significant advances have been made in our understanding of the processes occurring during $T$ cell activation. In part, these studies have led to more precise characterizations of the site of action of various immunosuppressive drugs. This in turn has enabled the design of immunosuppressive drug combinations that take advantage of nonoverlapping mechanisms of action, thus creating synergistic immunosuppression while minimizing drug-related toxicity. Thus cyclosporine, which blocks IL-2 (and other lymphokine) mRNA expression in most experimental systems (42), is combined with corticosteroids, 


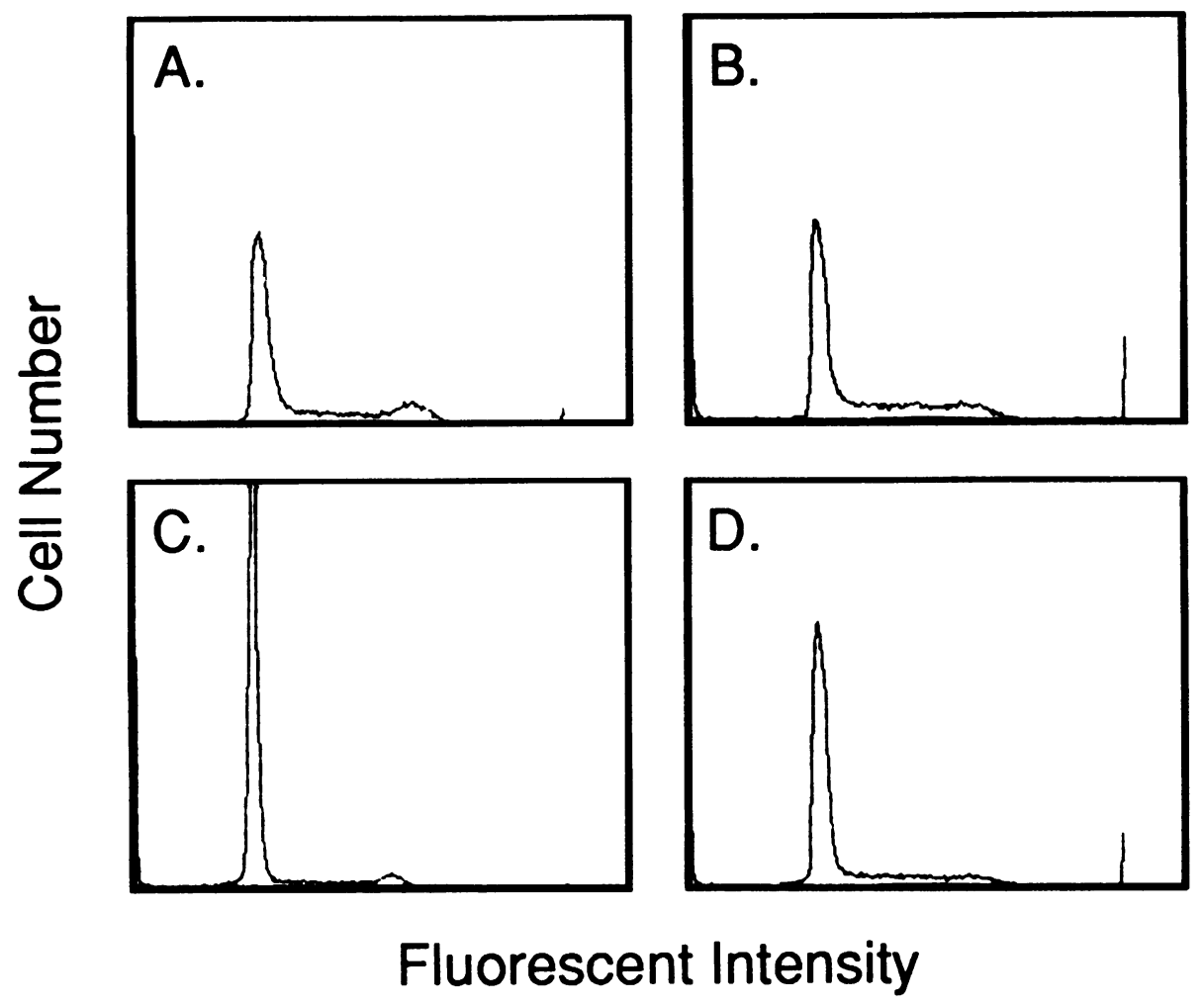

Figure 8. Mizoribine blocks cells from exiting $G 1$ and entering $S$ phase. Purified $T$ cells were stimulated with anti-CD3 MAb, harvested after $48 \mathrm{~h}$, stained with propidium iodide, and DNA content was analyzed by flow cytometry. Cells were stimulated in the absence $(A$ and $B$ ) or presence $(C$ and $D)$ of $2 \mu \mathrm{g} / \mathrm{ml}$ of mizoribine. The cultures shown in $B$ and $D$ were supplemented with $50 \mu \mathrm{M}$ guanosine plus $100 \mu \mathrm{M} 8$ aminoguanosine to replete intracellular GTP $(B$ and $D)$. Each panel displays fluorescence in arbitrary units on a linear scale. Equal numbers of cells were analyzed in each graph. The percentage of cells in $\mathrm{S}+\mathrm{G} 2+\mathrm{M}$ phases are: $(A)-$ $33 \%$; $(C)$ (mizoribine) $-21 \%$; $(B)$ (GTP repletion) $-45 \%$; and $(D)$ (mizoribine plus GTP repletion) $36 \%$. which block IL-1 secretion (43), and azathioprine, which blocks cell division (44).

The imidazole nucleoside mizoribine was first isolated from a soil fungus in 1974, and since then has proven efficacious in both clinical and experimental transplantation. Despite this, little is known of its mechanism of action. Our results demonstrate that mizoribine blocks the proliferation of $\mathrm{T}$ cells to a variety of mitogenic stimuli, without interfering with the initial phases of $\mathrm{T}$ cell activation.

The ability of mizoribine to inhibit $\mathrm{T}$ cell proliferation induced by either mitogens, which engage cell surface structures (e.g., anti-CD3 MAb or alloantigen), or by phorbol ester plus calcium ionophore, indicates that the effect of the drug is independent of cell membrane interactions and occurs after protein kinase $\mathrm{C}$ activation and intracellular calcium increases. Our findings that the expression of $c-m y c$ and IL-2 mRNA, and of the 55-kD IL-2R protein product is consistent with these observations, and demonstrates that mizoribine does not affect events occurring in the initial phases of G1. This finding was confirmed by cell cycle analysis which demonstrated that mizoribine-containing cultures had decreased numbers of cells in $\mathrm{S}, \mathrm{G} 2$, and $\mathrm{M}$ phases, thus indicating a blockade in the movement of cells from $\mathrm{G} 1$ to $S$. Since the expression of mRNA for cdc2 kinase, histone, and $c-m y b$ were each unaltered by mizoribine, the block can be further localized to a subphase late in $\mathrm{G} 1$ and distal to the $\mathbf{R}$ (restriction) point, after which cells become committed to mitotic division.

$\mathrm{T}$ cell unresponsiveness to IL-2, even in the presence of IL-2R expression, has been reported in other systems and is potentially a physiologic immunoregulatory mechanism (45). Consistent with this, the interaction of IL-2 with its receptor has been shown to induce $c-m y b$ expression and stimulate the progression of cells from G1 to S phase (46). Churilla et al. (47) have reported that in antigen-stimulated $T$ cell clones, the failure of IL-2R + cells to proliferate in response to IL-2 correlates with a lack of $c-m y b$ expression. In this study, mizoribine was also able to block the proliferation of naive $T$ cells, despite the sparing of IL-2 and IL-2 receptors. This effect however, must occur by a distinct mechanism, since we found no impairment of $c-m y b$ induction, implying that at least part of IL-2 signaling was unimpaired.

In an attempt to more precisely define the mechanism of action of the drug, we examined intracellular purine ribonucleotide pools, since mizoribine has been postulated to inhibit IMP dehydrogenase, an enzyme required for guanine nucleotide biosynthesis. These studies showed that mizoribine caused a dose-dependent depletion of intracellular GTP without significantly affecting ATP. When intracellular GTP was repleted using the combination of guanosine and 8-aminoguanosine, the antiproliferative action of mizoribine was reversed at all but the highest doses of the drug. Thus at low to moderate concentrations of mizoribine, inhibition of proliferation appears to be a direct consequence of GTP depletion. In contrast, at higher concentrations of mizoribine $(50 \mu \mathrm{g} / \mathrm{ml})$, we were unable to reverse the antiproliferative effects of the drug with GTP repletion, despite restoration of GTP levels to control values. As discussed earlier, we conclude that there may be additional mechanisms of action of mizoribine at high concentrations.

We did not observe depletion of adenine nucleotide pools at concentrations of mizoribine up to $10 \mu \mathrm{g} / \mathrm{ml}$, and adenine did not reverse the inhibitory effects of the drug (data not shown). Thus, our data provide direct evidence regarding the importance of GTP in T cell proliferation. Previous studies on cells from patients with purine nucleoside phosphorylase defi- 
ciency, all of whom have severely depressed cellular immunity, have demonstrated a depletion in GTP in the erythrocytes from some of these individuals $(48,49)$. However to our knowledge, this is the first report directly examining the effects of GTP depletion and repletion on $T$ cell activation and proliferation. It is of additional interest that while the site of action of azathioprine remains unknown despite extensive study and clinical use (44), its active metabolite, 6-thio-IMP, is capable of inhibiting IMP dehydrogenase (50), thereby causing changes in intracellular purine ribonucleotides similar to what we have observed with mizoribine. Of the known inhibitors of IMP dehydrogenase, only mycophenolic acid and tiazofurin have been used in large clinical trials. Mycophenolic acid has been moderately effective in the treatment of psoriasis (51), but was withdrawn from widespread use because of gastrointestinal toxicity. Tiazofurin was developed as an antineoplastic agent, but was associated with marked toxicity in phase I studies (52). The potential of either of these drugs to act as immunosuppressive agents has not been specifically evaluated.

As supported by our data (Fig. 2) and in vivo studies, mizoribine might be expected to be most useful in human allograft recipients when combined with cyclosporine and corticosteroids. An advantage of this regimen is that mizoribine does not appear to cause either myelosuppression or hepatotoxicity, both of which can occur with azathioprine. At doses of 1-3 $\mathrm{mg} / \mathrm{kg}$ per $\mathrm{d}$, mizoribine has proven safe and efficacious in human renal transplantation (4, 7-12). When measured, peak and trough mizoribine levels have been $\sim 5$ and $1 \mu \mathrm{g} / \mathrm{ml}$, respectively, concentrations that we have shown to act additively with cyclosporine in vitro. Our finding that mizoribine blocked GTP accumulation even when added after cell stimulation (Fig. 4), coupled with the observation that cell proliferation is similarly inhibited by exposure to mizoribine during the final hours of culture (16; and data not shown), suggests that mizoribine might be useful in modulating active immune responses as well as in preventing their initiation.

In conclusion, we have shown that mizoribine blocks $\mathrm{T}$ cell proliferation without interfering with proximal events in $T$ cell activation. The mechanism of action of mizoribine, when used in low doses, is depletion of intracellular GTP pools, which causes a block in transition of the cells from $G 1$ to $S$ phase in the cell cycle. While GTP depletion is known to be associated with inhibition of DNA synthesis per se (53), the lack of myelosuppression in patients treated with mizoribine argues against a non-specific antiproliferative effect at the doses used clinically. The apparent selective effect of this drug against $T$ cells in vivo may be related either to their relative levels of IMP dehydrogenase or to their more specific requirements for GTP. We are currently using in vitro models of lymphoid and nonlymphoid cell growth to confirm a $\mathrm{T}$ cell-specific effect of mizoribine and to examine the basis for this specificity.

\section{Acknowledgments}

The authors wish to thank Claire Rogers for technical assistance with flow cytometry, and the many investigators who donated reagents and cDNA probes. We also thank David Fox for his helpful critique of the manuscript.

This work was supported in part by National Institutes of Health (NIH) grants 1 K08 DK-01899-01, AR-20557, and 1 RO1 CA-34085. Dr. Turka is a recipient of an NIH Clinical Investigator Award. Dr.
Dayton was supported by the Pharmacology Training grant of the University of Michigan.

\section{References}

1. Amemiya, H., S. Suzuki, S. Niiya, H. Watanabe, and T. Kotake. 1988. Synergistic effect of cyclosporine and mizoribine on survival of dog renal allografts. Transplantation (Baltimore). 46:768-771.

2. Gregory, C. R., I. M. Gourley, G. R. Cain, T. W. Broaddus, L. D. Cowgill, N. H. Willits, J. D. Patz, and G. Ishizaki. 1988. Effects of combination cyclosporine/mizoribine immunosuppression on canine renal allograft recipients. Transplantation (Baltimore). 45:856-859.

3. Gregory, C. R., I. M. Gourley, S. C. Haskins, G. R. Cain, G. Ishizaki, L. D. Cowgill, N. H. Willits, and J. D. Patz. 1988. Effects of mizoribine on canine renal allograft recipients. Am. J. Vet. Res. 49:305-311.

4. Osakabe, T., H. Uchida, Y. Masaki, K. Sato, Y. Nakayama, M. Ohkubo, K. Kumano, T. Endo, K. Watanabe, and K. Aso. 1989. Studies on immunosuppression with low-dose cyclosporine combined with mizoribine in experimental and clinical cadaveric renal allotransplantation. Transplant. Proc. 21:1598-1600.

5. Okubo, M., Y. Masaki, K. Kamata, N. Sato, K. Inoue, and N. Umetani. 1989. Immunosuppressive mode of action of deoxyspergualin in mice, as compared with cyclosporine A and mizoribine. Transplant. Proc. 21:1085-1087.

6. Suzuki, S., T. Hijioka, I. Sakakibara, and H. Amemiya. 1987. The synergistic effect of cyclosporine and mizoribine on heterotopic heart and partial-lung transplantation in rats. Transplantation (Baltimore). 43:743-744.

7. Kusaba, R., O. Otubo, H. Sugimoto, I. Takahashi, Y. Yamada, J. Yamauchi, N. Akiyama, and T. Inou. 1981. Immunosuppressive effect of bredinin in the management of patients with renal transplantation. Proc. Eur. Dial. Transplant. Assoc. 18:420-425.

8. Amemiya, H., S. Suzuki, H. Watanabe, R. Hayashi, and S. Niiya. 1989. Synergistically enhanced immunosuppressive effect by combined use of cyclosporine and mizoribine. Transplant. Proc. 21:956-958.

9. Takahara, S., T. Fukunishi, Y. Kokado, Y. Ichikawa, M. Ishibashi, S., Nagano, and T. Sonoda. 1988. Combined immunosuppression with low-dose cyclosporine, mizoribine, and prednisolone. Transplant. Proc. 20:147-151.

10. Marumo, F., M. Okubo, K. Yokota, H. Uchida, K. Kumano, T. Endo, K. Watanabe, and N. Kashiwagi. 1988. A clinical study of renal transplant recipients receiving triple-drug therapy-cyclosporine $\mathrm{A}$, mizoribine, and prednisone. Transplant. Proc. 20:406-409.

11. Aso, K., H. Uchida, K. Sato, K. Yokota, T. Osakabe, Y. Nakayama, M. Ohkubo, K. Kumano, T. Endo, K. Koshiba, K. Watanabe, and N. Kashiwagi. 1987. Immunosuppression with low-dose cyclosporine combined with bredinin and prednisolone. Transplant. Proc. 19:1955-1958.

12. Tajima, A., M. Hata, N. Ohta, Y. Ohtawara, K. Suzuki, and Y. Aso. 1984. Bredinin treatment in clinical kidney allografting. Transplantation (Baltimore). 38:116-118.

13. Mizuno, K., M. Tsuijno, M. Takada, M. Hayashi, K. Atsumi, K. Asano, and T. Matsuda. 1974. Studies of Bredinin. Isolation, characterization and biological properties. J. Antibiot. (Tokyo). 27:775-782.

14. Koyama, H., and M. Tsuji. 1983. Genetic and biochemical studies on the activation and cytotoxic mechanism of bredinin, a potent inhibitor of purine biosynthesis in mammalian cells. Biochem. Pharm. 32:3527-3553.

15. Sakaguchi, K., M. Tsuijino, M. Hayashi, K. Kawai, J. Mizuno, and K. Hayand. 1976. Mode of action of bredinin with guanylic acid on L5178Y mouse leukemia cells. J. Antibiot. (Tokyo). 29:1320-1327.

16. Ichikawa, Y., H. Ihara, S. Takahara, K. Takada, G. R. Shrestha, M. Ishibashi, M. Arima, S. Sagawa, and T. Sonoda. 1984. The immunosuppressive mode of action of mizoribine. Transplantation (Baltimore). 38:262-267.

17. O'Shea, U., K. B. Urdahl, H. T. Luong, T. M. Chused, L. E. Samelson, and R. D. Klausner. 1987. Aluminum fluoride induces phosphatidylinositol turnover, elevation of cytoplasmic free calcium, and phosphorylation of the $\mathrm{T}$ cell antigen receptor in murine T cells. J. Immunol. 139:3463-3469.

18. Downward, J., J. A. Graves, P. H. Warne, S. Rayter, and D. A. Cantrell. 1990. Stimulation of P2 $1^{\text {ras }}$ upon T cell activation. Nature (Lond.). 346:719-723.

19. Ledbetter, J. A., M. Parsons, P. J. Martin, J. A. Hansen, P. S. Rabinovitch, and C. H. June. 1986. Antibody binding to CD5 (Tp67) and Tp44 T cell surface molecules: effects on cyclic nucleotides, cytoplasmic free calcium, and cAMPmediated suppression. J. Immunol. 137:3299-3305.

20. Martin, D. W., Jr., and E. Gelfand. 1981. Biochemistry of disease of immunodevelopment. Annu. Rev. Biochem. 50:845-877.

21. Weiss, A. 1989. T lymphocyte activation. In Fundamental Immunology. W. E. Paul, editor. Raven Press, Ltd., New York. 359-384.

22. Ledbetter, J. A., P. J. Martin, C. E. Spooner, D. Wofsy, T. T. Tsu, P. G. Beatty, and P. Gladstone. 1985. Antibodies to Tp67 and Tp44 augment and sustain proliferative responses of activated T cells. J. Immunol. 135:2331.

23. Ledbetter, J. A., H. P. Fell, L. S. Grosmaire, M. A. Norris, and T. T. Tsu. 
1987. An immunoglobulin light chain dimer with CD4 antigen specificity. $\mathrm{Mol}$. Immunol. 24:1255.

24. Ledbetter, J. A., T. T. Tsu, and E. A. Clark. 1985. Covalent association between human thymus-leukemia like antigens and CD8. J. Immunol. 134:4250

25. Martin, P. J., G. Longton, J. A. Ledbetter, W. Newman, M. P. Braun, P. G. Beatty, and J. A. Hansen. 1983. Identification and functional characterization of two distinct epitopes on the human T cell surface protein Tp50. J. Immunol. 131:180-185.

26. Turka, L. A., J. A. Ledbetter, K. Lee, C. H. June, and C. B. Thompson CD28 is an inducible $T$ cell surface antigen that transduces a proliferative signal in $\mathrm{CD}^{+}$mature thymocytes. J. Immunol. 144:1646-1653.

27. Ledbetter, J. A., C. H. June, L. S. Grosmaire, and P. S. Rabinovitch. 1987. Crosslinking of surface antigens causes mobilization of intracellular ionized calcium in T lymphocytes. Proc. Natl. Acad. Sci. USA. 84:1384.

28. Chirgwin, J. M., A. E. Przbyla, R. J. MacDonald, and W. J. Rutter. 1979. Isolation of biologically active ribonucleic acid from sources enriched in ribonuclease. Biochemistry. 18:5294.

29. Thompson, C. B., P. B. Challoner, P. E. Neiman, and M. Groudine. 1986. Expression of the c-myb proto-oncogene during cellular proliferation. Nature (Lond.). 319:374.

30. June, C. H., J. A. Ledbetter, M. M. Gillespie, T. Lindsten, and C. B. Thompson. 1987. $\mathrm{T}$-cell proliferation involving the CD28 pathway is associated with cyclosporine-resistant interleukin 2 gene expression. Mol. Cell. Biol. 7:4472

31. Sood, A. K., D. Pereira, and S. M. Weissman. 1981. Isolation and partia nucleotide sequence of a cDNA clone for human histocompatibility antigen HLA-B by use of an oligodeoxy-nucleotide primer. Proc. Natl. Acad. Sci. USA. 78:616-620.

32. Bentley, D. L., and M. Groudine. 1986. Novel promoter upstream of the human c-myc gene and regulation of c-myc expression in B-cell lymphomas. Mol. Cell. Biol. 6:3481-3489.

33. Clark, S. C., S. K. Arya, F. Wong-Staal, M. Matsumoto-Kobayashi, R. M. Kay, R. J. Kaufman, E. L. Brown, C. Shoemaker, T. Copeland, S. Oroszlan, K Smith, M. G. Sarngadharan, S. G. Linder, and R. C. Gallo. 1984. Human T-cell growth factor: partial amino acid sequence, $\mathrm{CDNA}$ cloning, and organization and expression in normal and leukemic cells. Proc. Natl. Acad. Sci. USA. 81:25432547.

34. Krieg, P. A. and D. A. Melton. 1984. Formation of the 3 ' end of histone mRNA by post-transcriptional processing. Nature (Lond.). 308:203-206.

35. Lee, M. G., and P. Nurse. 1987. Complementation used to clone a human homologue of the fission yeast cell cycle control gene cdc2. Nature (Lond.). 327:31-35

36. Thompson, C. B., T. Lindsten, J. A. Ledbetter, S. L. Kunkel, H. A. Young, S. G. Emerson, J. M. Leiden, and C. H. June. 1989. CD28 activation pathway regulates the production of multiple T-cell-derived lymphokines/cytokines. Proc Natl. Acad. Sci. USA. 86:1333-1337.

37. June, C. H., J. A. Ledbetter, T. Lindsten, and C. B. Thompson. 1989. Evidence for the involvement of three distinct signals en the induction of IL-2 gene expression in human T lymphocytes. J. Immunol. 143:153-161.

38. Sidi, Y., and B. S. Mitchell. 1984. 2'-Deoxyguanosine toxicity for B and mature $\mathrm{T}$ lymphoid cell lines is mediated by guanine ribonucleotide accumulation. J. Clin. Invest. 74:1640-1648.

39. Kazmers, I., B. S. Mitchell, P. Daddona, L. Wotring, L. Townsend, and W. N. Kelley. 1981. Inhibition of purine nucleoside phosphorylase by 8-aminoguanosine: selective toxicity for T lymphoblasts. Science (Wash.). 214:11371139.

40. Lindsten, T., C. H. June, and C. B. Thompson. 1988. Multiple mechanisms regulate c-myc gene expression during normal $\mathrm{T}$ cell activation. $E M B O$ (Eur. Mol. Biol. Organ.) J. 7:2787-2794.

41. Pardee, A. B. 1989. G, events and regulation of cell proliferation. Science (Wash.). 246:603-608.

42. Elliott, J. F., Y. Lin, S. B. Mizel, R. C. Bleackley, D. G. Harnish, and V. Paetkau. 1984. Induction of interleukin 2 messenger RNA inhibited by cyclosporin A. Science (Wash. DC.). 226:1439-1441.

43. Snyder, D. A., and E. R. Unanue. 1982. Corticosteroids inhibit munine macrophage la expression and interleukin-1 production. J. Immunol. 129:18031805.

44. Elion, G. B., and G. H. Hitchings. 1975. Azathioprine. In Handbook of Experimental Pharmacology. A. C. Sortorelli, and D. G. Johns, editors. Springer Publishing Co., New York. 404-425.

45. Williams, M. E., A. H. Lichtman, and A. K. Abbas. 1990. Anti-CD3 antibody induces unresponsiveness to IL- 2 in Th 1 clones but not in Th2 clones. $J$. Immunology. 144:1208-1214.

46. Stern, J. B., and K. A. Smith. 1986. Interleukin-2 induction of T-cell G progression and c-myb expression. Science (Wash. DC). 233:203-206.

47. Churilla, A. M., T. J. Braciale, and V. L. Braciale. 1989. Regulation of T lymphocyte proliferation: interleukin 2-mediated induction of $c-m y b$ gene ex pression is dependent on T lymphocyte activation state. J. Exp. Med. 170:105121.

48. Simmonds, H. A., A. R. Watson, D. R. Webster, A. Sahota, and D. Perrett. 1982. GTP depletion and other erythrocyte abnormalities in inherited PNP deficiency. Biochem. Pharmacol. 31:941-946.

49. Cohen, A., L. J. Gudas, A. J. Ammann, G. E. J. Stall, and D. W. Martin Jr. 1978. Deoxyguanosine triphosphate as a possible toxic metabolite in the im munodeficiency associated with purine nucleoside phosphorylase deficiency. $J$. Clin. Invest. 78:1405-1409.

50. Kelley, W. N., F. M. Rosenbloom, and J. E. Seegmiller. 1967. The effects of azathioprine (Imuran) on purine synthesis in clinical disorders of purine metabolism. J. Clin. Invest. 46:1518-1529.

51. Epinette, W. W., C. M. Parker, E. L. Jones, and M. C. Greist. 1987. Mycophenolic acid for psoriasis: a review of pharmacology, long term efficacy, and safety. J. Am. Acad. Derm. 17:962-971.

52. Melink, T. J., D. D. Van Hoff, J. G. Kuhn, M. R. Hersh, L. A. Sternson, T. T. Patton, R. Siegler, D. H. Boldt, and G. M. Clark. 1985. Phase I evaluation and pharmacokinetics of tiazofurin (2- $\beta$-D-ribofuranosylthiazole-4-carbozmaide). Cancer Res. 45:2859-2865.

53. Cohen, M. B., J. Maybaum, and W. Sadee. 1981. Guanine nucleotide depletion and toxicity in mouse T lymphoma (S-49) cells. J. Biol. Chem 256:8713-8717. 